\title{
PENGARUH KUALITAS PELAYANAN FISKUS DAN SANKSI PERPAJAKAN TERHADAP KEPATUHAN WAJIB PAJAK ORANG PRIBADI DI KPP PRTAMA KARAWANG UTARA
}

\author{
Yunita Susanti ${ }^{1}$ \\ Suhono ${ }^{2}$ \\ Fakultas Ekonomi Universitas Singaperbangsa Karawang, Jawa Barat, \\ Indonesia ${ }^{1,2}$ \\ Email: yunitasusanti13@gmail.com ${ }^{1}$ Suhono@fe.unsika.ac.id ${ }^{2}$
}

\begin{abstract}
This study aims to determine the effect of the quality of tax services and tax sanctions on individual taxpayer compliance at KPP Pratama Karawang Utara. One of the supports that can help the country's development is through state revenue in the form of taxes. Contribution of revenue from the taxation sector is expected to increase every year. In an effort to increase the tax revenue, the Directorate General of Taxation has reformed the taxation system into a Self Assessment System. Hypothesis testing in this study was conducted using Multiple Linear Regression Analysis. This research was conducted at KPP Pratama Karawang Utara. The study population was 273,322 individual taxpayers. The sampling technique used was purposive sampling, the determination of the number of samples was carried out using the Slovin formula, in order to obtain the number of respondents as many as 100 individual taxpayers. The results of the research partially show that the Quality of Fiscal Service and Tax Sanctions have a positive and significant effect on Individual Taxpayer Compliance.
\end{abstract}

Keywords: Fiscus Service Quality; Tax Sanction; Taxpayer Compliance

\begin{abstract}
ABSTRAK
Penelitian ini bertujuan untuk mengetahui pengaruh Kualitas Pelayanan Fiskus dan Sanksi Perpajakan terhadap Kepatuhan Wajib Pajak Orang Pribadi di KPP Pratama Karawang Utara. Salah satu penunjang yang dapat membantu pembangunan negara adalah melalui pendapatan negara berupa pajak Kontribusi penerimaan dari sektor perpajakan diharapkan semakin meningkat setiap tahunnya. Dalam upaya untuk meningkatkan penerimaan pajak tersebut, maka Direktorat Jenderal Pajak melakukan reformasi sistem perpajakan menjadi Self Assessment System. Uji hipotesis dalam penelitian ini dilakukan dengan menggunakan Analisis Regresi Linear Berganda. Penelitian ini dilakukan pada KPP Pratama Karawang Utara. Populasi penelitian sebanyak 273.322 Wajib Pajak Orang Pribadi. Teknik pengambilan sampel yang digunakan adalah Purposive Sampling, penentuan jumlah sampel dilakukan dengan menggunakan rumus slovin, sehingga diperoleh jumlah responden sebanyak 100 Wajib Pajak Orang Pribadi. Hasil penelitian secara parsial menunjukan bahwa Kualitas Pelayanan Fiskus dan Sanksi Perpajakan berpengaruh positif dan signifikan terhadap Kepatuhan Wajib Pajak Orang Pribadi.
\end{abstract}

Kata kunci: Kualitas Pelayanan Fiskus; Sanksi Perpajakan; Kepatuhan Wajib Pajak. 


\section{PENDAHULUAN}

Negara Indonesia merupakan salah satu negara berkembang yang saat ini sedang giat melakukan pembangunan dari segala bidang di berbagai wilayah di Indonesia, hal tersebut dilakukan pemerintah untuk menciptakan Indonesia sebagai negara yang maju dan dapat berdaya saing tinggi dengan negara lain baik itu dari segi sosial, ekonomi, politik maupun budaya. Saat ini program pemerintah yang paling gencar dilakukan untuk mewujudkan Indonesia sebagai negara yang maju ialah melaksanakan program pembangunan insfratuktur, sebab pembangunan insfratuktur ini dianggap akan meningkatkan konektivitas dan merangsang daya saing antar daerah diseluruh Indonesia (Kompas, 2020).

Salah satu penunjang yang dapat membantu pembangunan negara adalah melalui pendapatan negara berupa pajak. Peranan pajak bagi pendapatan negara memiliki kontribusi yang dominan. Sebab menurut Undang-Undang No. 16 Tahun 2009 mengenai perubahan ke empat atas Undang-Undang No. 6 Tahun 1983 tentang ketentuan umum dan tata cara perpajakan pasal 1 ayat 1 menjelaskan bahwa pajak merupakan kontribusi wajib yang dilakukan negara secara terutang baik oleh orang pribadi maupun badan dengan tidak memperoleh imbalan secara langsung dengan tujuan untuk digunakan bagi keperluan negara, yang sebesarbesarnya bagi kemamkmuran masayarakat (Mardiasmo, 2016).

Kontribusi penerimaan dari sektor perpajakan diharapkan semakin meningkat setiap tahunnya. Dalam upaya untuk meningkatkan penerimaan pajak tersebut, maka Direktorat Jenderal Pajak melakukan reformasi sistem perpajakan menjadi Self Assessment System. Akan tetapi dalam menjalankan self assessment 
system tentu tidak selalu berjalan sesuai dengan yang diharapkan agar wajib pajak tersebut dapat mematuhi kewajiban perpajakannya.

Seperti kondisi yang terjadi di KPP Pratama Karawang Utara, dimana banyaknya wajib pajak orang pribadi yang terdaftar serta efektif di KPP Pratama Karawang Utara seringkali tidak seimbang dengan banyaknya wajib pajak orang pribadi yang menyampaikan Surat Pemberitahuan setiap tahunnya, Hal tersebut dapat kita lihat pada tabel tingkat kepatuhan wajib pajak orang pribadi yang terdaftar di KPP Pratama Karawang Utara tahun 2015 - 2019 berikut ini :

Tabel 1.

Persentase Tingkat Kepatuhan WP OP dalam menyampaikan SPT di KPP Pratama Karawang Utara Tahun 2015 - 2019

\begin{tabular}{ccccc}
\hline Tahun & $\begin{array}{c}\text { WP OP } \\
\text { Terdaftar }\end{array}$ & $\begin{array}{c}\text { WP OP } \\
\text { Efektif }\end{array}$ & $\begin{array}{c}\text { WP OP Yang } \\
\text { Menyampaikan SPT }\end{array}$ & $\begin{array}{c}\% \\
\text { Kepatuhan }\end{array}$ \\
\hline 2015 & 156.941 & 99.900 & 58.790 & $58,84 \%$ \\
2016 & 173.872 & 109.482 & 56.783 & $51,86 \%$ \\
2017 & 194.290 & 86.208 & 57.083 & $66,21 \%$ \\
2018 & 212.359 & 91.224 & 67.291 & $73,76 \%$ \\
2019 & 273.322 & 84.457 & 42.116 & $49,86 \%$ \\
\hline
\end{tabular}

Sumber : KPP Pratama Karawang Utara, 2020

Berdasarkan tabel 1 menunjukan bahwa terjadinya kondisi yang fluktuatif terhadap tingkat kepatuhan wajib pajak orang pribadi di KPP Pratama Karawang Utara, pada tahun 2016 - 2017 terjadinya peningkatan terhadap tingkat kepatuhan wajib pajak orang pribadi mencapai 14,35\% dan 2017 - 2018 terjadiya peningkatan terhadap tingkat kepatuhan wajib pajak orang pribadi mencapai 7,55\%, sedangkan pada tahun 2015 - 2016 menunjukan bahwa tingkat kepatuhan wajib pajak orang pribadi menurun sebesar 6,98\% dan 2018 - 2019 terjadinya penurunan terhadap tingkat kepatuhan wajib orang pribadi sebesar 23,9\%, berdasarkan data tersebut tentu menunjukan bahwa masih adanya suatu kondisi 
yang memperlihatkan masih rendahnya tingkat kepatuhan wajib orang pribadi di KPP Pratama Karawang Utara. Tentu saja kondisi tersebut dapat disebabkan oleh beberapa faktor yang mempengaruhi kepatuhan wajib pajak.

Terdapat beberapa faktor yang dapat mempengaruhi kepatuhan wajib pajak, diantaranya pelayanan yang diberikan petugas kepada wajib pajak dan kualitas penegakan hukum perpajakan yang berupa sanksi perpajakan (Rahayu, 2017). Oleh karena itu, negara dituntut untuk memberikan pelayanan yang terbaik agar masyarakat dapat ikut berperan aktif dalam melaksanakan suatu kegiatan perpajakan.

Pelayanan petugas pajak tentu sangat berperan penting dalam mempengaruhi Wajib Pajak. Sebab kualitas pelayanan harus mencapai tujuan yang diharapkan yaitu meningkatkan kepuasan Wajib Pajak dan kepatuhan Wajib Pajak. Dalam memberikan kualitas pelayanan, tentu saja terdapat beberapa aturan dan tata cara yang telah ditetapkan dan harus diterapkan dalam kegiatan pemberian pelayanan.

Penelitian terdahulu mengenai pengaruh Kualitas Pelayanan Fiskus terhadap Kepatuhan Wajib Pajak Orang Pribadi memperoleh hasil yang tidak konsisten. penelitian yang dilakukan oleh Lubis (2017) menyatakan bahwa Kualitas Pelayanan berpengaruh signifikan terhadap Kepatuhan Wajib Pajak, penelitian yang dilakukan oleh Susmita \& Supadmi (2016) menyatakan bahwa Kualitas Pelayanan berpengaruh positif terhadap Kepatuhan Wajib Pajak Orang Pribadi. Sedangkan penelitian yang dilakukan oleh Ghailina (2018) menyatakan bahwa Kualitas Pelayanan Fiskus tidak berpengaruh terhadap Kepatuhan Wajib 
Pajak Orang Pribadi.

Dalam hal peningkatan penerimaan pajak selain kualitas pelayanan petugas pajak yang berpengaruh terhadap peningkatan kepatuhan Wajib Pajak, terdapat faktor lain yang dapat berpengaruh terhadap kepatuhan Wajib Pajak yaitu kualitas penegakan hukum perpapjakan berupa sanksi perpajakan. Agar peraturan perpajakan dipatuhi oleh Wajib Pajak, maka harus ada sanksi perpajakan bagi para pelanggarnya.

Sanksi perpajakan merupakan akibat yang diterima oleh Wajib Pajak ketika Wajib Pajak tidak mematuhi peraturan perpajakan (Ermawati \& Afifi, 2018). Hal ini menunjukan bahwa dalam pelaksanaan penerimaan pajak tidak selalu berjalan dengan lancar sesuai dengan yang diharapkan, sebab terdapat banyak faktor yang membuat Wajib Pajak tidak melakukan pelaporan Wajib Pajak atau lambat dalam melakukan pembayaran kewajiban pajaknya. Sehingga tindakan tersebut dapat dikatakan sebagai Wajib Pajak tidak mematuhi peraturan perpajakan.

Penelitian terdahulu mengenai pengaruh Sanksi Perpajakan terhadap Kepatuhan Wajib Pajak Orang Pribadi memperoleh hasil yang tidak konsisten. Penelitian yang dilakukan oleh Halawa \& Saragih (2017) menyatakan bahwa Sanksi Perpajakan berpengaruh positif dan signifikan terhadap Kepatuhan Wajib Pajak, penelitian yang dilakukan oleh Arifin \& Nasution (2017) menyatakan bahwa Sanksi Perpajakan berpengaruh signifikan terhadap Kepatuhan Wajib Pajak. Sedangkan penelitian yang dilakukan oleh Bahri et al.,(2019) menyatakan bahwa Sanksi Perpajakan tidak berpengaruh terhadap Kepatuhan Wajib Pajak. 
Dalam upaya untuk mencapai tujuan perpajakan, pemberian pelayanan petugas pajak dan sanksi perpajakan tentu saja tidak selalu berjalan sesuai dengan yang direncanakan, sehingga hal tersebut dapat berakibat pada rendahnya tingkat kepatuhan wajib pajak dalam membayarkan kewajibannya. Dengan rendahnya tingkat kepatuhan wajib pajak tersebut maka akan berakibat pada tidak terealisasinya capaian target yang telah disusun atau dirancang oleh pemerintah dalam penerimaan pajak secara maksimal.

\section{METODE PENELITIAN}

Metode penelitian yang digunakan adalah metode deskriptif dan metode verifikatif. Metode deskriptif ini digunakan untuk mendeskripsikan mengenai Kualitas Pelayanan Fiskus dan Sanksi Perpajakan sebagai varaiabel independen dan Kepatuhan Wajib Pajak Orang Pribadi sebagai variabel dependent. Sedangkan metode verifikatif dilakukan dengan tujuan untuk menguji hipotesis dengan perhitungan statistik.

Jenis data yang digunakan dalam penelitian ini adalah data sekunder dan data primer. Data sekunder dalam penelitian ini berupa data-data yang berkenaan dengan data mengenai tingkat kepatuhan Wajib Pajak Orang Pribadi yang terdaftar di KPP Pratama Karawang Utara, sedangkan data primer dalam penelitian ini dilakukan dengan mengumpulkan data berupa kuesioner yang berisi mengenai pernyataan-pernyataan yang akan diajukan oleh peneliti kepada responden mengenai Kualitas Pelayanan Fiskus, Sanksi Perpajakan dan Kepatuhan Wajib Pajak Orang Pribadidan diukur menggunakan skala likert 1 sampai dengan $5(1=$ Sangat Tidak Setuju dan $5=$ Sangat Setuju $)$. 
Populasi dalam penelitian ini adalah seluruh Wajib Pajak Orang Pribadi yang terdaftar di KPP Pratama Karawang Utara, penentuan jumlah sampel dalam penelitian ini dilakukan dengan menggunakan rumus slovin dengan tingkat standar error yang di tolerir adalah 10\%. Sehingga diperoleh jumlah sampel sebanyak 100 responden Wajib Pajak Orang Pribadi di KPP Pratama Karawang Utara.

Pengambilan sampel dalam penelitian ini menggunakan purposive sampling. Adapun kriteria dalam penentuan sampel dalam penelitian ini adalah Wajib pajak orang pribadi yang terdaftar di KPP Pratama Karawang Utara, Wajib pajak orang pribadi yang telah memiliki Nomor Pokok Wajib Pajak (NPWP) sebagai identitas diri dan Wajib pajak orang pribadi yang tercatat serta beraktivitas di KPP Pratama Karawang Utara.

Hipotesis dalam penelitian ini diuji dengan menggunakan analisis regresi liner berganda dengan alat bantu SPSS 25. Sehingga diperoleh persamaan sebagai berikut :

$$
\mathrm{Y}=\alpha+\beta 1 . \mathrm{X} 1+\beta 2 . \mathrm{X} 2+\varepsilon
$$

Keterangan :

$Y \quad=$ Variabel Terikat (kepatuhan wajib pajak)

$\alpha \quad=$ Konstanta

$\beta 1 \operatorname{dan} \beta 2=$ Koefesien Regresi

$\mathrm{X} 1$ dan X2 = Variabel bebas (Kualitas pelayanan fiskus dan sanksi perpajakan)

$\varepsilon \quad=$ Standar Error

\section{HASIL DAN PEMBAHASAN}

Uji kualitas data digunakan untuk mengetahui apakah instrumen yang digunakan valid dan reliabel, sebab kebenaran data yang diolah sangat 
menentukan kualitas hasil penelitian. Uji kualitas data dalam penelitian ini dilakukan dengan uji validitas dan reliabilitas.

Uji validitas ini dilakukan untuk mengetahui sejauh mana suatu alat pengukur dapat mengukur apa yang diukur. Uji validitas yang dilakukan dalam penelitian ini ialah dengan menggunakan pendekatan person correlation. Hasil pengujian dalam penelitian ini menunjukan bahwa nilai $r$ hitung $>r$ tabel $(0,1946)$ untuk masing-masing dari item pernyataan sehingga dapat dinyatakan valid secara keseluruhan.

Uji reliabilitas dalam penelitian ini menggunakan pendekatan cronbach alpha, dimana apabila nilai koefesien cronbach alpha> 0,60 maka construct dinyatakan reliabel. Berdasarkan hasil pengujian reiabilitas dalam penelitian ini menunjukan bahwa setiap variabel memiliki nilai cronbach alpha $>0,60$.

Dimana pada variabel Kualitas Pelayanan Fiskus (X1) memperoleh nilai cronbach alpha sebesar $(0,678)$, variabel Sanksi Perpajakan memperoleh nilai cronbach alpha sebesar $(0,839)$, dan variabel Kepatuhan Wajib Pajak Orang Pribadi memperoleh nilai cronbach alpha sebesar $(0,797)$ sehingga dapat dikatakan bahwa seluruh variabel dalam penelitian ini dapat dinyatakan reliabel.

Pengujian normalitas data dalam penelitian ini dilakukan dengan one sample kolmogrov smirnov, dengan ketentuan apabila nilai signifikan $>0.05$ maka distribusi normal $\left(\mathrm{H}_{0}\right.$ diterima) sedangkan apabila nilai signifikan $<0.05$ maka distribusi tidak normal ( $\mathrm{H}_{0}$ ditolak). Berdasarkan hasil uji normalitas diperoleh nilai signifikan pada Asymp. Sig. (2-tailed) sebesar 0,071>0,05 atau di atas 0,05. Maka dapat disimpulkan bahwa nilai residual berdistribusi normal. 
Tabel 2.

Hasil Uji Normalitas

Unstandarized Residual

$\mathrm{N}$

100

Asymp. Sig. (2-tailed) , $071^{\mathrm{c}}$

Sumber :Hasil Olah Data SPSS 25, 2020

Pengujian multikolinearitas dalam penelitian ini diukur dari nilai tolerance serta variance inflation factor (VIF). Nilai tolerance yang rendah sama dengan nilai VIF tinggi (sebab VIF $=1 /$ Tolerance). Nilai cut off yang umum dipakai untuk menunjukan adanya multikolinearitas adalah nilai tolerance $<0.10$ atau sama dengan nilai VIF $>10$.

Tabel 3.

Hasil Uji Multikolinearitas

\begin{tabular}{|c|c|c|c|}
\hline \multirow[t]{2}{*}{ Variabel } & \multicolumn{2}{|c|}{$\begin{array}{l}\text { Collinearity } \\
\text { Statistic }\end{array}$} & \multirow[t]{2}{*}{ Keterangan } \\
\hline & Tolerance & VIF & \\
\hline \multicolumn{4}{|l|}{ (Constant) } \\
\hline Kualitas Pelayanan Fiskus & ,833 & 1,201 & Tidak terjadi Multikolinearitas \\
\hline Sanksi Perpajakan & ,833 & 1,201 & Tidak terjadi Multikolinearitas \\
\hline
\end{tabular}

Dari hasil pengujian diperoleh nilai tolerance dan VIF untuk masingmasing variabel independen (Kualitas Pelayanan Fiskus dan Sanksi Perpajakan) adalah sebagai berikut : nilai tolerance sebesar $0,833>0,10$ dan nilai VIF (Variance Inflation Factor) pada masing-masing variabel sebesar 1,201 < 10. Maka dapat dikatakan bahwa data tersebut tidak terjadi multikolinearitas antar variabel independen.

Dalam penelitian ini, yang digunakan untuk mengetahui ada tidaknya 
gejala heteroskedatisitas adalah dengan melihat grafik scatter plot.

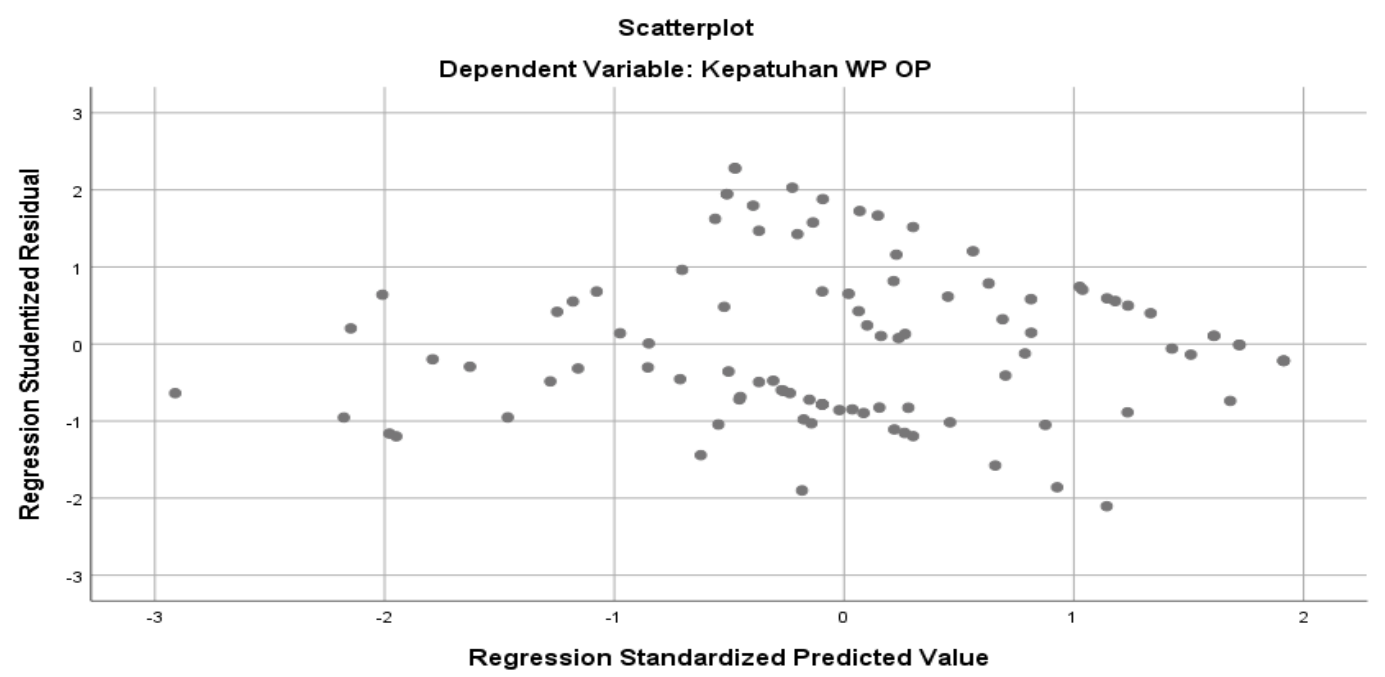

Sumber :Hasil Olah Data SPSS 25, 2020

\section{Gambar 1. \\ Hasil Uji Heteroskedastisitas}

Dari hasil pengujian menunjukan bahwa bahwa titik-titik data penyebaran tersebut menyebar di atas dan di bawah angka 0 pada sumbu Y dan penyebaran titik-titik data tersebut tidak terdapat pola yang jelas seperti bergelombang, melebar, dan menyempit. Sehingga dapat disimpukan bahwa pada data tersebut tidak terjadi heteroskedastisitas.

Analisis deskriptif dalam penelitian ini dilakukan dengan menggunakan skala ordinal dan rentang skala untuk menganalisis data yang diperoleh dengan menggambarkan pengaruh Kualitas Pelayanan Fiskus dan Sanksi Perpajakan Terhadap Kepatuhan Wajib Pajak Orang Pribadi. Hasil analisis deskriptif dalam penelitian ini dapat dilihat pada hasil rekapitulasi indikator masing-masing variabel. (Hasil olah data dilampirkan)

Hasil analisis deskriptif pada variabel Kualitas Pelayanan Fiskus 
menunjukan bahwa total skor pada variabel independen yaitu Kualitas Pelayanan Fiskus sebesar 7439 dengan nilai rata-rata nya sebesar 413,3 yang berada pada rentang skala 340,1 - 420 dengan kriteria setuju. Sehingga untuk Variabel Kualitas Pelayanan Fiskus dinyatakan setuju oleh responden, hal ini menggambarkan bahwa petugas pajak di KPP Pratama Karawang Utara telah memenuhi dimensi dari kualitas pelayanan fiskus. Dimana, pada 16 indikator dengan 18 pernyataan, skor tertinggi berada pada indikator ke 9 dan 10 yaitu mengenai fasilitas gedung, kerapihan dan kondisi setiap ruangan dan skor terendah ada pada indikator ke 4 mengenai pelayanan, hal ini disebabkan karena adanya persepsi dari sebagian responden yang merasakan kurangnya pelayanan yang diberikan oleh fiskus dalam hal memberikan jaminan tepat waktu pada saat memberikan pelayanan kepada wajib pajak orang pribadi di KPP Pratama Karawang Utara.

Selanjutnya hasil analisis deskriptif pada variabel Sanksi Perpajakan menunjukan bahwa total skor pada variabel independen yaitu Sanksi Perpajakan sebesar 1350 dengan nilai rata-rata nya sebesar 337,5 yang berada pada rentang skala 260,1 - 340 dengan kriteria cukup setuju. Hal ini menggambarkan bahwa penerapan sanksi perpajakan masih perlu ditingkatkan agar dapat meningkatkan kepatuhan wajib pajak orang pribadi di KPP Pratama Karawang Utara. Dimana, pada 3 indikator dengan 4 pernyataan, skor tertinggi berada pada indikator ke -1 yaitu bunga $2 \%$ perbulan dan skor terendah ada pada indikator ke - 3 yaitu kenaikan pembayaran pajak, hal ini disebabkan karena adanya persepsi dari sebagian responden yang merasa keberatan dalam pengenaan sanki perpajakan 
berupa kenaikan pembayaran pajak tersebut. Sehingga hal tersebut tentu dapat berpengaruh pada tingkat Kepatuhan Wajib Pajak Orang Pribadi dalam melakukan kewajiban perpajakanya, maka dalam hal ini diperlukan adanya suatu ketegasan yang dilakukan oleh fiskus agar dapat meminimalkan rendahnya tingkat kepatuhan wajib pajak tersebut dengan memberikan tekanan berupa sanksi perpajakan secara efektif, teritegritas dan pemeriksaan pajak yang dilakukan dengan baik dan tepat sasaran.

Hasil analisis deskriptif pada variabel Kepatuhan Wajib Pajak Orang Pribadi menunjukan bahwa total skor sebesar 3013 dengan nilai rata-rata nya sebesar 430,4 yang berada pada rentang skala 420,1 - 500 dengan kriteria sangat setuju. Hal ini menggambarkan bahwa Wajib Pajak Orang Pribadi di KPP Pratama Karawang Utara telah patuh akan kewajiban perpajakannya. Dimana, 7 indikator dengan 7 pernyataan, skor tertinggi berada pada indikator ke -1 dan ke - 2 yaitu memenuhi persayaratan pendaftaran NPWP dan Mengisi formulir dan skor terendah ada pada indikator ke -5 yaitu dilakukan sesuai dengan self assessment system, hal ini disebabkan karena adanya persepsi dari sebagian responden yang merasa belum paham mengenai sistem tersebut yang berakibat pada rendahnya tingkat kepatuhan wajib pajak.

Sehingga diperlukan adanya suatu sosialisasi dari fiskus, adanya pelayanan berkualitas yang diberikan fiskus kepada wajib pajak orang pribadi dan adanya ketegasan pada kualitas penegakan hukum yang berupa sanksi perpejakan bagi para pelanggarnya di KPP Pratama Karawang Utara, sebab hal tersebut sangat penting agar dapat meningkatkan motivasi atau keinginan Wajib Pajak 
Orang Pribadi di KPP Pratama Karawang Utara dalam melakukan kewajiban perpajakannya sesuai dengan self assessment system tersebut.

Tabel 4.

Hasil Analisis Regresi Linear Berganda

\begin{tabular}{clcccc}
\hline & & \multicolumn{2}{c}{ Unstandardized Coeficients } & \multirow{2}{*}{ T } & \multirow{2}{*}{ Sig. } \\
Model & & B & Std. Error & & \\
\hline \multirow{4}{*}{1} & (Constant) & 8,508 & 2,355 & 3,613 & \multirow{2}{*}{000} \\
& Kualitas Pelayanan & & & & \\
& Fiskus &, 259 &, 031 & 8,407 &, 000 \\
& Sanksi Perpajakan &, 234 &, 117 & 2,008 &, 047 \\
\hline \multicolumn{2}{l}{ Sumber $\cdot$ Hasil Olah Data SPSS 25, 2020 } & & & &
\end{tabular}

Hasil persamaan analisis regresi linear berganda adalah sebagai berikut :

Kepatuhan WP OP $(\mathrm{Y})=8,508+$ 0,259 Kualitas Pelayanan Fiskus + 0,234 Sanksi

\section{Perpajakan}

Diketahui bahwa nilai konstanta sebesar 8,508 artinya apabila variabel dependen yaitu Kepatuhan Wajib Pajak Orang Pribadi (Y) tidak dipengaruhi oleh kedua variabel independen yaitu Kualitas Pelayanan fiskus (X1) dan Sanksi Perpajakan (X2) sama dengan 0 (nol), maka rata-rata Kepatuhan Wajib Pajak Orang Pribadi akan bernilai sebesar 8,508.

Nilai koefesien regresi pada masing-masing variabel independennya menggambarkan apabila diperkirakan variabel independennya naik satu unit dan variabel independen lainnya diperkirakan konstan atau setara dengan nol, maka variabel dependen diperkirakan bisa naik atau turun sesuai dengan tanda koefesien regresi linear berganda.

Koefesien regresi untuk variabel X1 yaitu Kualitas Pelayanan Fiskus bernilai positif, artinya terdapat hubungan yang searah antara Kualitas Pelayanan Fiskus (X1) dengan Kepatuhan Wajib Pajak Orang Pribadi (Y). Koefesien regresi 
X1 sebesar 0,259 yang berarti bahwa setiap kenaikan Kualitas Pelayanan Fiskus sebesar satu poin maka Kepatuhan Wajib Pajak Orang Pribadi dapat mengalami kenaikan sebesar 0,259 .

Koefesien regresi untuk variabel X2 yaitu Sanksi Perpajakan bernilai positif, artinya terdapat hubungan yang searah antara Sanksi Perpajakan (X2) dengan Kepatuhan Wajib Pajak Orang Pribadi (Y). Koefesien regresi X2 sebesar 0,234 yang berarti bahwa setiap kenaikan Kualitas Pelayanan Fiskus sebesar satu poin maka Kepatuhan Wajib Pajak Orang Pribadi dapat mengalami kenaikan sebesar 0,234.

Dapat dilihat $\mathrm{t}$ hitung pada setiap variabel penelitian, dapat digunakan untuk memperoleh suatu kesimpulan menerima atau menolak $\mathrm{H}_{0}$, hal tersebut harus ditentukan terlebih dahulu menggunakan tingkat signifikansi 5\% dan menggunakan uji 2 sisi karena k-2, maka dapat diperoleh nilai t tabel $(\mathrm{df}=\mathrm{n}-\mathrm{k})$ atau $(\mathrm{df}=100-3=97)$ maka diperoleh nilai t tabel sebesar 1,98472 .

Pada variabel Kualitas Pelayanan Fiskus, hasil pengujian diperoleh nilai t hitung sebesar 8,407 > t tabel sebesar 1,98472 dan diperoleh nilai signifikansi sebesar $0,000<0,05$. Sehingga dapat disimpulkan bahwa $\mathrm{H}_{0}$ di tolak dan $\mathrm{H}_{\mathrm{a}}$ di terima. Dengan demikian, dapat disimpulkan bahwa terdapat Pengaruh Kualitas Pelayanan Fiskus Terhadap Kepatuhan Wajib Pajak Orang Pribadi.

Pada variabel Sanksi Perpajakan diiperoleh nilai t hitung sebesar 2,008 > t tabel sebesar 1,98472 dan diperoleh nilai signifikansi sebesar 0,047 $<0,05$. Sehingga dapat disimpulkan bahwa $\mathrm{H}_{0}$ di tolak dan $\mathrm{H}_{\mathrm{a}}$ di terima. Dengan demikian, dapat disimpulkan bahwa terdapat Pengaruh Sanksi Perpajakan 
Terhadap Kepatuhan Wajib Pajak Orang Pribadi.

Pengujian secara simultan dilakukan untuk mengetahui apakah variabel bebas yang ada dalam model memiliki pengaruh secara bersama-sama terhadap variabel terikat. Untuk mengetahui nilai $\mathrm{F}$ tabel dengan signifikasi 5\% dengan rumus $\mathrm{df}=(\mathrm{k} ; \mathrm{n}-\mathrm{k}-1$ )atau sama dengan $\mathrm{df}=(2 ; 100-2-1=97)$ maka dapat dilihat nilai $\mathrm{F}$ tabel yaitu 3,09. Hasil pengujian hipotesis secara simultan dalam penelitian ini adalah sebagai berikut :

Tabel 5. Hasil Uji F

\begin{tabular}{|c|c|c|c|c|}
\hline Model & & $\mathbf{F}$ & Sig. & Keterangan \\
\hline 1 & Regression & 53,137 &, $000^{\mathrm{b}}$ & berpengaruh \\
\hline
\end{tabular}

Sumber :Hasil Olah Data SPSS 25, 2020

Berdasarkan hasil pengujian diperoleh nilai $\mathrm{F}$ hitung sebesar 53,137 > F tabel 3,09 dan nilai signifikansi yang di dapat sebesar $0,000<0,05$. Sehingga dapat disimpulkan bahwa $\mathrm{H}_{0}$ di tolak dan $\mathrm{H}_{\text {a. }}$ diterima. Dengan demikian, dapat disimpulkan bahwa terdapat pengaruh secara simultan Kualitas Pelayanan Fiskus dan Sanksi Perpajakan terhadap Kepatuhan Wajib Pajak Orang Pribadi.

Uji koefesien determinasi digunakan sebagai ukuran untuk mengatahui seberapa besar kemampuan dari variabel independen yaitu Kualitas Pelayanan Fiskus dan Sanksi Perpajakan dapat berpengaruh terhadap variabel dependen yaitu Kepatuhan Wajib Pajak Orang Pribadi yang dinyatakan dalam persentase. Semakin tinggi nilai koefisinen determinasi maka semakin tinggi pula pengaruh variabel independen terhadap variabel dependen. Pengujian ini dilakukan dengan menggunakan alat bantu SPSS 25, dimana diperoleh hasil analisis koefesien determinasi (R2) adalah sebagai berikut : 
Tabel 6.

Uji Koefesien Detrminasi

Model Summary ${ }^{b}$

\begin{tabular}{ccccr}
\hline Model & R Square & $\begin{array}{c}\text { Adjusted R } \\
\text { Square }\end{array}$ & \multicolumn{1}{c}{ Std. Error of the Estimate } \\
\hline 1 &, 523 &, 513 & 3,550392 \\
\hline Sumber :Hasil Olah Data SPSS 25,2020 &
\end{tabular}

Sumber :Hasil Olah Data SPSS 25, 2020

Hasil pengujian menunjukan hasil pengolahan data, dimana nilai koefesien determinasi (R2) yang ditunjukan dalam kolom R Square yaitu sebesar 0,523 atau sebesar 52,3\%. Maka dapat disimpulkan bahwa variabel independen yaitu Kualitas Pelayanan Fiskus dan Sanksi Perpajakan berpengaruh sebesar 52,3\% terhadap variabel dependen yaitu Kepatuhan Wajib Pajak Orang Pribadi di KPP Pratama Karawang Utara, sedangkan sisanya sebesar 47,7\% Kepatuhan Wajib Pajak Orang Pribadi di KPP Pratama Karawang Utara dipengaruhi oleh variabel lain yang tidak diteliti dalam penelitian ini.

Pengaruh Kualitas Pelayanan Fiskus terhadap Kepatuhan Wajib Pajak Orang Pribadi. Hasil analisis data membuktikan bahwa Kualitas Pelayanan Fiskus berpengaruh terhadap Kepatuhan Wajib Pajak Orang Pribadi. Dalam hal ini dikarenakan pelayanan yang diberikan fiskus kepada wajib pajak harus sesuai dengan layanan yang diinginkan oleh wajib pajak maka fiskus harus mampu memberikan pelayanan yang terbaik kepada wajib pajak, sehingga akan memberikan kesan yang baik dan nyaman serta dapat mendorong wajib pajak rela melakukan kewajiban perpajaknya kepada negara, sehingga hal tersebut akan mengakibatkan meningkatnya tingkat Kepatuhan Wajib Pajak Orang Pribadi di KPP Pratama Karawang Utara. Dengan demikian, dapat disimpulkan bahwa apabila kualitas pelayanan fiskus yang diberikan kepada wajib pajak semakin 
meningkat maka akan meningkatkan kepatuhan wajib pajak dalam melakukan kewajiban perpajakannya.

Hasil penelitian ini sesuai dengan teori yang dikemukakan olehRahayu (2017) yang menyatakan bahwa: apabila suatu sistem administrasi berjalan secara efektif maka dapat memberikan dampak dalam peningkatan kualitas pelayanan pajak yang akan diberikan fiskus pada wajib pajak. Hal ini dapat membuat wajib pajak rela untuk membayarkan pajaknya kepada negara, tanpa mengharapkan imbalan secara langsung. Hasil penelitian ini sejalan dengan penelitian yang dilakukan oleh Arifin \& Nasution (2017)dimana hasil penelitian tersebut menyatakan bahwa kualitas pelayanan memiliki pengaruh secara parsial terhadap kepatuhan wajib pajak.

Pengaruh Sanksi Perpajakan terhadap Kepatuhan Wajib Pajak Orang Pribadi. Hasil analisis data membuktikan bahwa Sanksi Perpajakan berpengaruh terhadap Kepatuhan Wajib Pajak Orang Pribadi. Dalam hal ini, penerapan sanksi perpajakan tentu harus sesuai dengan norma perpajakan yang telah ditetapkan sehingga dapat memberikan sanksi, baik itu sanksi administrasi maupun sanksi pidana kepada para pelanggarnya, dengan adanya tekanan berupa sanksi perpajakan yang diberikan fiskus kepada wajib pajak yang melanggar maka akan mengakibatkan meningkatnya tingkat Kepatuhan Wajib Pajak Orang Pribadi di KPP Pratama Karawang Utara. Dengan demikian, dapat disimpulkan bahwa apabila penerapan sanksi perpajakan semakin baik maka akan meningkatkan kepatuhan wajib pajak dalam melakukan kewajiban perpajakannya. 
Hasil penelitian ini sesuai dengan teori yang dikemukakan oleh Rahayu (2017) yang menyatakan bahwa : kepatuhan wajib pajak dapat meningkat melalui tekanan yang diberikan kepada wajib pajak agar tidak melakukan suatu pelanggaran pajak. Hasil penelitian ini sejalan dengan penelitian yang dilakukan oleh Arifin \& Nasution (2017)dimana hasil penelitian tersebut menyatakan bahwa sanksi perpajakan memiliki pengaruh secara parsial terhadap kepatuhan wajib pajak.

Pengaruh Kualitas Pelayanan Fiskus dan Sanksi Perpajakan terhadap Kepatuhan Wajib Pajak Orang Pribadi. Hasil analisis data membuktikan bahwa Kualitas Pelayanan Fiskus dan Sanksi Perpajakan berpengaruh terhadap Kepatuhan Wajib Pajak Orang Pribadi. Dimana semakin berkualitas pelayanan yang diberikan fiskus kepada wajib pajak dan semakin berkualitas penegakan hukum perpajakan yang berupa sanksi perpajakan kepada para pelanggarnya, maka akan mengakibatkan meningkatnya tingkat Kepatuhan Wajib Pajak Orang Pribadi di KPP Pratama Karawang Utara.

Hasil penelitian ini sesuai dengan teori yang dikemukakan oleh Rahayu (2017)yang menyatakan bahwa terdapat beberapa faktor yang dapat mempengaruhi kepatuhan wajib pajak dua diantaranya ialah kualitas pelayanan perpajakan yang diberikan kepada wajib pajak dan kualitas penegakan hukum perpajakan berupa sanksi perpajakan.

Hasil penelitian ini sejalan dengan penelitian yang dilakukan oleh Arifin \& Nasution (2017)dimana hasil penelitian tersebut menyatakan bahwa kualitas pelayanan dan sanksi perpajakan memiliki pengaruh secara simultan terhadap 
kepatuhan wajib pajak.

\section{SIMPULAN DAN SARAN}

Berdasarkan hasil penelitian yang telah dijelaskan, maka dapat diperoleh simpulan sebagai berikut :Kualitas Pelayanan Fiskus secara parsial berpengaruh positif dan signifikan terhadap Kepatuhan Wajib Pajak Orang Pribadi. Sanksi Perpajakan secara parsial berpengaruh positif dan signifikan terhadap Kepatuhan Wajib Pajak Orang Pribadi. Dan Kualitas Pelayanan Fiskus dan Sanksi Perpajakan secara simultan berpengaruh positif dan sigifikan terhadap Kepatuhan Wajib Pajak Orang Pribadi.

Berdasarkan kesimpulan di atas serta hal-hal yang terkait dengan keterbatasan penelitian ini, maka terdapat beberapa saran yang perlu dikemukakan diantaranya : bagi KPP Pratama Karawang Utara adalah Petugas pajak diharapkan dapat lebih memperhatikan kembali kualitas pelayanan yang diberikan kepada wajib pajak, sehingga dapat meningkat penerimaan pajak atau wajib pajak dapat patuh akan kewajiban perpajakannya serta petugas pajak diharapkan lebih aktif lagi dalam memberikan informasi dan pemungutan pajak, sehingga wajib pajak akan tahu kapan harus membayarkan kewajiban perpajakannya dan terhindar dari sanksi perpajakan.

\section{REFERENSI}

Arifin, S. B., \& Nasution, A, A. (2017). Pengaruh Kesadaran Wajib Pajak dan Sanksi Pajak Terhadap Penerimaan Pajak di Kantor Pelayanan Pajak Pratama Medan Barat. Jurnal Riset Akuntansi \& Bisnis.3(02). 177-186. hhtps://doi.org/10.31289/jab.v3i12.1237

As'ari, N. G., (2018). PENGARUH PEMAHAMAN PERATURAN 
PERPAJAKAN, KUALITAS PELAYANAN, KESADARAN WAJIB PAJAK DAN SANKSI PAJAK TERHADAP KEPATUHAN WAJIB PAJAK ORANG PRIBADI. Ekonomi.2(1) 46-55. https://doi.org/10.22201/fq.18708404e.2004.3.66178

Bahri, S., Diantimala, Y., \& Majid, M. (2019). PENGARUH KUALITAS PELAYANAN PAJAK, PEMAHAMAN PERATURAN PERPAJAKAN SERTA SANKSI PERPAJAKAN TERHADAP KEPATUHAN WAJIB PAJAK (Pada Kantor Pajak KPP Pratama Kota Banda Aceh). JURNAL $\begin{array}{llll}\text { PERSPEKTIF EKONOMI DARUSSALAM. 3(02). } & 177-186\end{array}$ https://doi.org/10.24815/jped.v4i2.13044

Ermawati, N., \& Afifi, Z. (2018). Pengaruh Pengatuhan Perpajakan Dan Sanksi Perpajakan Terhadap Kepatuhan Wajib Pajak Dengan Religiusitas Sebagai Variabel Pemoderasi. Prosiding SENDI_U. 7(2). 49-62. https://doi.org/10.30659/jai.7.2.49-62

Halawa, J., \& Saragih, J. L. (2017). Pengaruh Kebijakan Dividen, Kebijakan Utang dan Profitabilitas terhadap Nilai Perusahaan pada Perusahaan Manufaktur yang terdaftar di Bursa Efek Indonesia. Jurnal Riset Dan $\begin{array}{lll}\text { Akuntansi } & \text { (JRAK). 3(02). 243-256. }\end{array}$ hhtps://doi.org/10.1234/Akuntansi.v3i2.449

Kompas. (2018). \$ tahun Jokowi-Jk dan Catatan Pembangunan Infrastruktur. https://nasional.kompas.com/read/2018/10/20/14144381/4-tahun0jokowi-jkdan-catatan-pembangunan-infrastruktur?page=all. (diunduh tanggal 20 Februari 2020)

Lubis, R. H. (2017). Pengaruh Kualitas Pelayanan Perpajakan, dan Sanksi Perpajakan terhadap Kepatuhan Wajib Pajak di KPP Pratama Medan Belawan. In JKBM (JURNAL KONSEP BISNIS DAN MANAJEMEN). 4(11). 12-44. https://doi.org/10.31289/JKBM.V4I1.1244

Mardiasmo. (2016). Perpajakan Edisi Revisi 2016. In Journal of Chemical Information and Modeling.

Rahayu, S. K. (2017). Perpajakan (Konsep dan Aspek Formal. In Rekayasa Sains.

Rara Susmita, P., \& Supadmi, N. (2016). Pengaruh Kualitas Pelayanan, Sanksi Perpajakan, Biaya Kepatuhan Pajak, Dan Penerapan E-Filing Pada Kepatuhan Wajib Pajak. E-Jurnal Akuntansi.14(02). 1239-1269. https://ojs.unud.ac.id/index.php/Akuntansi/Article/View/15146 